\title{
TEMPORAL ANALYSIS OF THE GENETIC DIVERSITY IN A HONEY BEE MATING AREA OF AN ISLAND POPULATION (LA PALMA, CANARY ISLANDS, SPAIN)
}

\author{
Irene Muñoz, Pilar De la Rúa
}

\author{
Dpto. de Zoología y Antropología Física, Facultad de Veterinaria, \\ Universidad de Murcia, Campus de Espinardo, 30100 Murcia, Spain. \\ e-mail: pdelarua@um.es
}

Received 28 October 2011; accepted 05 February 2012

$\mathrm{S}$ u m m a r y

A law to conserve the honey bee population on La Palma (Canary Islands) was stated in 2001. The introduction of foreign subspecies was prohibited. A natural mating area for local queens was established at the northeast section of the island. To evaluate the genetic diversity of the honey bee colonies located in this area, analyses of the mitochondrial (tRNA ${ }^{\text {leu }}-\operatorname{cox} 2$ intergenic region) and nuclear (five microsatellite loci) variation were performed by comparing two surveys conducted in 1998 and 2006 (i.e., before and after the conservation program started in 2001). While mitochondrial variability changed significantly in this area over the period analyzed, such differences were not observed at the nuclear level. These data may have implications relating to the control of selected colonies included in the conservation program. This is particularly true regarding the introduction of the colonies to other islands of the archipelago.

Keywords: Apis mellifera, conservation, genetic variability, La Palma, Spain.

\section{INTRODUCTION}

The Atlantic archipelagos of volcanic origin located in the North Atlantic Ocean, next to Europe and North Africa (Azores, Madeira and Savage Islands \{Portugal\}, Canary Islands \{Spain\} and Cape Verde) are collectively known as Macaronesia. This group of islands offers the possibility to perform interesting case studies of the consequences of anthropogenic activities. The biodiversity of this region consists of a mix of biological families found in the North Atlantic Ocean, the Mediterranean area, and Africa. The Canary Islands constitute an important hotspot of biodiversity, with over 3,000 animal and 524 plant species endemic to the region (Martín et al., 2005). However in the Canaries, people have introduced at least 1,434 species, of which approximately 150 are considered invasive (Martín et al., 2005). This makes effective isolation measures necessary to conserve those populations which have successfully adapted locally. Such a requirement is especially needed if such populations are threatened by hybridization with introduced related taxa, given the consequent introgression events and gene flow.

Apis mellifera $\mathrm{L}$. is one such introduced species, more specifically - the European subspecies Apis mellifera carnica and $A$. m. ligustica. These subspecies are considered imported globally by beekeepers (De la Rúa et al., 2009), putting at risk the conservation of native honey bee subspecies, populations, or ecotypes (Moritz et al., 2005). Genetic analysis of the black Canary honey bee populations (De la Rúa et al., 1998, 2001) revealed that these populations are differentiated from continental populations and more closely related to Moroccan than Iberian populations, even though some morphological similarities between the Canarian and Iberian populations have been demonstrated (Ruttner, 1988; 
Padilla-Alvarez et al., 1997). These Canarian populations, along with others from Madeira and the Azores, are included in a subset of the African evolutionary lineage with Atlantic distribution named $A_{\text {III }}$ (De la Rúa et al., 2006). These bees are characterized by mitochondrial haplotypes rarely found in populations from Iberia and Africa (Franck et al., 2001; Miguel et al., 2007; De la Rúa et al., 2007; Cánovas et al., 2008). So, these haplotypes are considered as mitochondrial markers for Canary Island honey bee populations.

The introduction of other honey bee subspecies into Canarian populations has been demonstrated by analyzing the variation of mitochondrial DNA (mtDNA: De la Rúa et al., 1998, 2002) and microsatellites loci (De la Rúa et al., 2001). As mtDNA is maternally inherited, analysis of one worker honey bee can provide information about the maternal ancestry of an entire colony, and of the patterns of introduction of foreign honey bee queens. By contrast, microsatellite sequences are biparentally inherited nuclear markers, and they yield useful information about population events such as introgressive hybridization. In honey bees, introgression occurs through mating between foreign drones and local queens. Unlike other domesticated animals, mating is rarely controlled in honey bees making gene flow between introduced and local populations common. Introgression can then progress very rapidly (Jensen et al., 2005). In a 1998 survey, introduced queens were detected on Tenerife (35\%), El Hierro (18\%), Gran Canaria (8\%) and La Gomera ( $2 \%$ ), but not on La Palma (De la Rúa et al., 2001) based on the detection of foreign mitochondrial haplotypes.

Prompted by the local beekeeping association and the government of the Canary Islands, a program to select and preserve the local black honey bee was initiated on La Palma in 2001. This population was adequate for conservation since introduced queens had not been detected, although some indication of hybridization was evident from nuclear analyses (De la Rúa et al., 1998, 2001). The regional laws which were passed included special measures to control the conservation, recuperation and selection of the Canary black honey bee, including prohibition of the introduction of other honey bee subspecies (B.O.C. 49 of 20/4/2001). Among other activities, a natural mating area (NMA) was established. This was favored by the particular topography at the northeast of the island which allowed for the saturation of this area with local drones. In this northeast section, local honey bee queens mated exclusively with local drones. These queens were then distributed among the local beekeepers.

In this study, we examined the possible changes in genetic variation occurring at the natural mating area by comparing two surveys carried out in 1998 and 2006. Finally, we discuss the potential for disseminating queens mated on La Palma to other islands where beekeepers are interested in using the Canary black honey bee.

\section{MATERIALS AND METHODS}

The study was performed on the island of La Palma, the most north-westerly of the Canary Islands in the Atlantic Ocean. This island has an area of $706 \mathrm{~km}^{2}$. In 1998 , the honey bee colony census was 1524, whereas in 2006 it increased to 3552 ( 5 colonies per $\mathrm{km}^{2}$ ). Beekeeping is mainly a hobby. There are less than 30 colonies per beekeeper.

At the natural mating area (NMA), a total of 25 colonies were settled in 1998 and 28 colonies in 2006. Samples of worker honey bees were collected from the inner combs of every colony located at the NMA each year. These samples were stored in absolute ethanol at $-20^{\circ} \mathrm{C}$ until processing (Fig. 1).

One worker bee per colony was used to analyze mitochondrial and microsatellite markers. Total DNA was extracted from the leg of the worker bee using the Chelex ${ }^{\circledR}$ method (Walsh et al., 1991). 
Mitochondrial analysis was performed as described previously (Garnery et al., 1993). PCR amplification of the intergenic tRNA $^{\text {leu-cox}} 2$ region was achieved in a total reaction volume of $25 \mu \mathrm{L}$ containing: $4 \mu \mathrm{L}$ DNA, $10 \mathrm{mM}$ Tris-HCl, $50 \mathrm{mM}$ $\mathrm{KCl}, 1.5 \mathrm{mM} \mathrm{MgCl}, 0.2 \mathrm{mM}$ of each $\mathrm{dNTP}, 0.5 \mu \mathrm{M}$ of each primer and $2.5 \mathrm{U}$ of PuReTaq DNA polymerase (GE Healthcare). The program cycle employed was as follows: denaturation for $5 \mathrm{~min}$ at $95^{\circ} \mathrm{C} ; 36$ cycles of $45 \mathrm{~s}$ at $95^{\circ} \mathrm{C}, 60 \mathrm{~s}$ annealing at $47^{\circ} \mathrm{C}$ and extension for $90 \mathrm{~s}$ at $72^{\circ} \mathrm{C}$; then a final elongation step of $10 \mathrm{~min}$ at $72^{\circ} \mathrm{C}$. The size of the PCR amplified products was determined following electrophoretic separation on $1.5 \%$ agarose gel. The fragments obtained when $20 \mu \mathrm{L}$ of the amplified products were digested by the DraI restriction enzyme at $37^{\circ} \mathrm{C}$ overnight, were visualized in $4 \%$ NuSieve agarose stained with ethidium bromide and photographed under UV light. Amplicons of haplotypes belonging to the $\mathrm{C}$ lineage were purified with isopropanol and ammonium acetate, and sequenced (Secugen S.L., Madrid, Spain) with the E2 primer. Each sequence was manually checked for base calling, and a multiple sequence alignment was performed with the MEGA program, version 4 (Tamura et al., 2007).

Population genetic parameters, haplotype patterns, and genetic diversity were calculated using GenAlEx software (Peakall and Smouse, 2006). Analysis of molecular variance (AMOVA) was calculated using ARLEQUIN version 3.1 (Excoffier et al., 2005) to evaluate the temporal effects on mitochondrial variation on La Palma. The number of permutations used in the AMOVA test was 16,000, which guaranteed less than a $1 \%$ difference with exact probability in $99 \%$ of the cases (Guo and Thomson, 1992). The Fisher's exact test was performed to test for differences in mitochondrial haplotype frequencies in the NMA between surveys.

Multiplex PCR reactions with five microsatellite loci (A7, A113, Ap43, Ap55 and B124: Estoup et al., 1995) were performed in a total volume of $10 \mu \mathrm{L}$ containing: $1 \mathrm{x}$ reaction buffer (Netline), $1.2 \mathrm{mM} \mathrm{MgCl}_{2}, 0.3 \mathrm{mM}$ of each dNTP, $0.4 \mu \mathrm{M}$ of each primer (one of each pair fluorescence-labeled), $3 \mathrm{U}$ of Taq polymerase (Netline) and $2 \mu \mathrm{L}$ of DNA extract. The PCR was performed as follows: one cycle of $5 \mathrm{~min}$ at $95^{\circ} \mathrm{C} ; 36$ cycles at $95^{\circ} \mathrm{C}$ for $30 \mathrm{~s}, 54^{\circ} \mathrm{C}$ for $30 \mathrm{~s}$ and $72^{\circ} \mathrm{C}$ for $30 \mathrm{~s}$; and a $30 \mathrm{~min}$ extension at $72^{\circ} \mathrm{C}$. Amplicons were processed using a 3730 automatic sequencer (Applied Biosystems) and the alleles were subsequently scored using GeneMapper v3.7 software (Applied Biosystems).

Standard parameters of population genetics, obtained using GenAlEx (Peakall and Smouse, 2006), were used to describe genetic variability. Genetic variation in the NMA between surveys, was evaluated by computing the number of alleles, allelic richness, allele frequencies, and the observed (Ho) and expected (He) heterozygosity.

Exact tests of the Hardy-Weinberg equilibrium (HWE) and the $U$ test for heterozygote deficiency were performed using Genepop 4.0 software (Rousset, 2008). To study the influence of evolutionary lineages on the distribution of the genotypes, the Fst (FSTAT program, Goudet, 2001) and AMOVA (program ARLEQUIN) values were calculated. The temporal influence on genetic variation between the two surveys in the NMA was quantified by analysis of molecular variance (AMOVA). In this analysis, the total variation of the microsatellite allele frequencies was divided into a within-population and between-survey component.

\section{RESULTS}

Only two haplotypes were detected in 1998, A14 being the more frequent $(0.600)$. Five haplotypes were detected in 2006, of which A15 was the most abundant (0.429, Tab. 1). Overall, the haplotype diversity increased at the NMA between 1998 (0.500) and 2006 (0.704). The analysis of molecular variance (AMOVA) 
showed that most of the variation was due to the variation between surveys at the NMA $(71.05 \%)$, while $28.95 \%$ was due to differences within the surveys, suggesting a temporal influence on the genetic diversity of the NMA (Tab. 2). Significant differences in haplotype frequency at the NMA were observed between surveys $(\mathrm{P}=0.000$, Fisher's test).

In terms of the $A_{\text {III }}$ sublineage, the frequency of the A14 haplotype decreased from 0.600 in 1998 to 0.036 in 2006, while that of the A15 haplotype increased from
0.000 to 0.429 in the same period. The A11 haplotype was not detected in 1998 but it was found at a frequency of 0.179 in 2006. Overall, the frequency of the $A_{\text {III }}$ sublineage typical of the Canarian honey bee populations increased from 0.600 in 1998 to 0.643 in 2006 (Fig. 1). The frequency change was not significant when the Fisher's test was used $(\mathrm{P}=0.883)$.

In 1998, the number of alleles per locus ranged from two (Ap43) to seven (B124), whereas they varied from three (A113, Ap43 and Ap55) to seven (B124) in 2006

Table 1 .

Frequency of each mitochondrial haplotype

at the natural mating area (NMA). D = haplotypic diversity

\begin{tabular}{||c|c|c|c|c|c|c|c||}
\hline \hline Survey & $\mathrm{n}$ [colonies] & $\mathrm{A} 1$ & $\mathrm{~A} 11$ & $\mathrm{~A} 14$ & $\mathrm{~A} 15$ & $\mathrm{C} 2 \mathrm{j}$ & $\mathrm{D}$ \\
\hline 1998 & 25 & 0.400 & & 0.600 & & & 0.500 \\
\hline 2006 & 28 & 0.321 & 0.179 & 0.036 & 0.429 & 0.036 & 0.704 \\
\hline
\end{tabular}

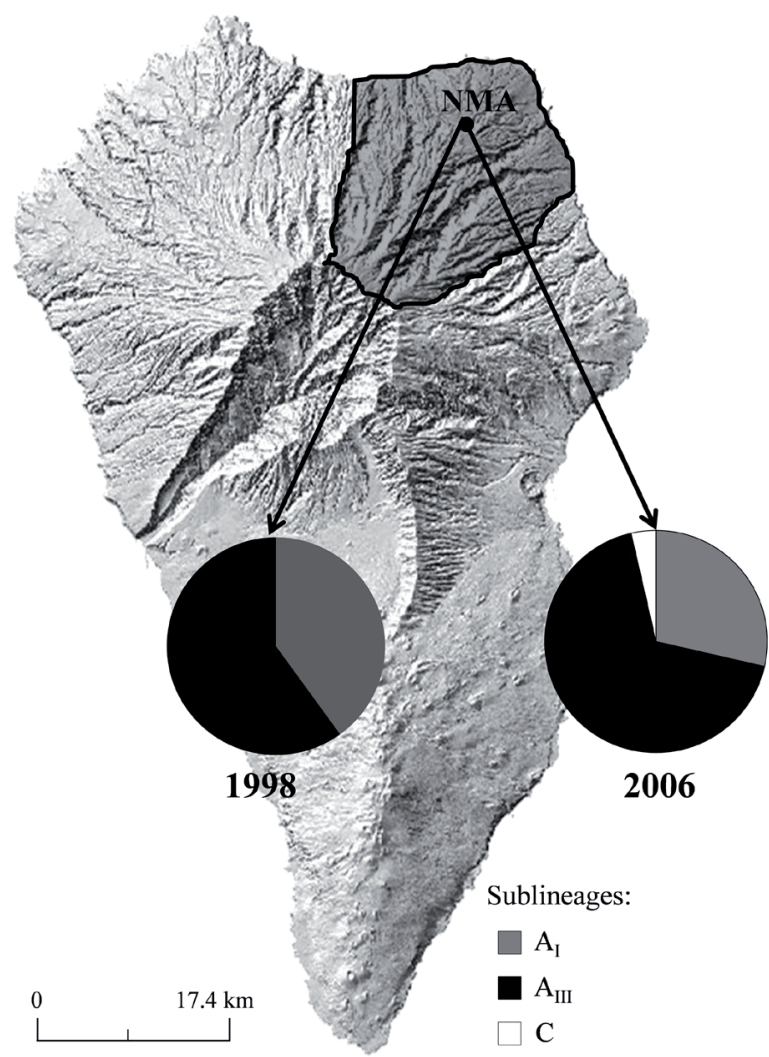

Fig. 1. Distribution and frequency of each African sublineage and the $\mathrm{C}$ lineage inferred from mitochondrial data at the natural mating area (NMA) located at the northeast of La Palma in 1998 and 2006. 
(Tab. 3). The mean number of alleles per locus (4.0) and total number of alleles (20) did not vary between 1998 and 2006. While the Ap43 locus exhibited an increase in the number of alleles, a decrease in allele number was observed at the A113 locus over this 8 year period. The mean heterozygosity values observed were 0.437 in 1998 and 0.454 in 2006, whereas the mean expected heterozygosity values were 0.495 and 0.524 , respectively. No significant differences in heterozygosity or allelic frequency were observed between the two surveys $(P=0.724$, Tab. 3). The Fisher's test revealed no significant temporal differentiation in the allelic frequencies.

Significant deviation from the HardyWeinberg equilibrium was detected in $2006(\mathrm{P}=0.009)$ but not in 1998 $(\mathrm{P}=0.143)$. Moreover, no significant difference was detected in the pairwise Fst value between the surveys in the NMA
(0.007). The AMOVA test (microsatellite data) showed that only a small fraction $(3.05 \%)$ of the total observed variation was due to temporal variation in the NMA between surveys (Tab. 2).

\section{DISCUSSION}

Our results demonstrate that at the natural mating area created through the conservation program aimed to preserve the local honey bee population on $\mathrm{La}$ Palma, there are honey bee queens introduced from other evolutionary lineages. Although at a very low frequency (3.6\% of the total number of colonies sampled in 2006), foreign honey bees have been found in this natural mating area. This is the area established to rear local queens and these queens are to be distributed among the Canarian beekeepers.

The introduction of honey bee queens with superior productive characteristics is common in modern beekeeping,

Table 2 .

AMOVA design and results: percentages of variation based on mtDNA

and microsatellite data in bees sampled from the natural mating area (NMA) in 1998 and 2006

\begin{tabular}{||c|c|c||}
\hline NMA 1998/2006 & mtDNA & microsatellite \\
\hline Among surveys & 28.95 & 3.05 \\
\hline Within surveys & 71.05 & 96.95 \\
\hline
\end{tabular}

Table 3 .

Sample size (N), number of alleles (Na), observed (Ho) and expected

(He) heterozygosity values based on microsatellite data from the colonies located at the natural mating area (NMA) on La Palma in 1998 and 2006

\begin{tabular}{||c|c|c|c|c|c||}
\hline $\begin{array}{c}\text { Year } \\
\text { (survey) }\end{array}$ & Locus & $\mathrm{N}$ & $\mathrm{Na}$ & Ho & He \\
\hline \multirow{5}{*}{1998} & $\mathrm{~A} 113$ & 19 & 4 & 0.526 & 0.614 \\
\cline { 2 - 6 } & $\mathrm{A} 7$ & 25 & 4 & 0.240 & 0.474 \\
\cline { 2 - 6 } & $\mathrm{Ap} 43$ & 25 & 2 & 0.360 & 0.420 \\
\cline { 2 - 6 } & $\mathrm{Ap55}$ & 25 & 3 & 0.560 & 0.545 \\
\cline { 2 - 6 } & $\mathrm{B} 124$ & 18 & 7 & 0.500 & 0.421 \\
\cline { 2 - 6 } & Mean & 22.4 & 4.0 & 0.437 & 0.495 \\
\hline \multirow{5}{*}{2006} & $\mathrm{~A} 113$ & 26 & 3 & 0.654 & 0.607 \\
\cline { 2 - 6 } & $\mathrm{A} 7$ & 26 & 4 & 0.269 & 0.527 \\
\cline { 2 - 6 } & Ap43 & 26 & 3 & 0.385 & 0.437 \\
\cline { 2 - 6 } & Ap55 & 26 & 3 & 0.538 & 0.587 \\
\cline { 2 - 6 } & B124 & 26 & 7 & 0.423 & 0.461 \\
\cline { 2 - 6 } & Mean & 26.0 & 4.0 & 0.454 & 0.524 \\
\hline \hline
\end{tabular}


although its long-term impact in locally adapted populations has not yet been assessed. The introduction (or importation) of foreign subspecies not only exposes native populations to pathogens but also to introgressive hybridization (De la Rúa et al., 2009). Exposure to foreign pathogens may have catastrophic consequences, while introgressive hybridization modifies the genetic pool of local adapted honey bee populations. This can alter the genetic identity and the fitness of the local population. The mixing of gene pools by introgression can generate "genetic pollution" depending on the species or subspecies (in the case of importation of foreign queens) introduced (Rhymer and Simberloff, 1996). While conservation programs have been established to prevent this effect, the genetic diversity of local populations may be diminished, as described in other animal populations (Allendorf et al., 2008).

The two main introduced honey bee subspecies A. m. carnica and A. m. ligustica, belong to the East European evolutionary C-lineage. They are valued for their mild temperament and their ease of management when it comes to honey production and crop pollination. These features have led to the introduction of these subspecies in many European and African countries (El-Niweiri and Moritz, 2010), the Macaronesian islands (De la Rúa et al., 2006), and in Australia and the Americas (Moritz et al., 2005). On the Canary Islands, the frequency at which honey bees bearing the $\mathrm{C}$ haplotype were detected differed on each island (De la Rúa et al., 1998, 2001). Specifically, no bees with C haplotype were observed on La Palma in 1998 (although this data was obtained from a reduced number of colonies). Prompted by beekeepers eager to protect the local honey bee, the Canary Islands government introduced a protection law banning the introduction of honey bees of other subspecies into the island. But our analysis of the 2006 survey suggests that not all beekeepers have adhered to this regulation. In any case, queens from the colonies in which $\mathrm{C}$ haplotypes have been detected should be excluded from the conservation program and replaced with indigenous queens. This replacement should be done particularly in those colonies located in the natural mating area which aims to provide local queens for beekeepers involved in the conservation program.

In the natural mating area, five haplotypes, three of them characteristic of the African sublineage with Atlantic distribution, were detected in 2006 (but one foreign $\mathrm{C}$ haplotype was also included). Thus, the genetic variability evident at the mitochondrial level had changed significantly since 1998, when only two haplotypes were detected. This observation suggests that the conservation program has affected the genetic diversity of the queens in the NMA by increasing the number of queens bearing different $\mathrm{A}_{\mathrm{III}}$ haplotypes. On the other hand, no significant change in the nuclear diversity (taking into consideration the drone genes too) was detected over the study period in the NMA. These results are reflected in the parameters of heterozygosity or allelic richness measured with microsatellite markers. The lack of nuclear diversity may be because of the saturation with local drones from many colonies in the mating area, where free mating of selected Canarian queens occurs. Paternal gene flow from drones derived from introduced queens may also contribute to genetic introgression (Clarke et al., 2002). For these reasons, colonies comprised of imported honey bee stock and/or the resulting hybrids after mating with local honey bee queens, should be excluded from the conservation program as stated before.

The conservation program introduced in 2001 has had an impact on mitochondrial diversity, as indicated by the significant change that ensued in haplotype frequencies, despite a slight increase in the presence of the Atlantic African $A_{\text {III }}$ sublineage. Although the program had no observable impact on the nuclear (microsatellite) diversity of the honey bee population in the period investigated, the 
genetic analysis suggests the presence of imported stock on the island. These data may be important to control the selected colonies included in the conservation program. This is especially true if these colonies are to be introduced into other Islands of the archipelago. Recently, significant losses of honey bee colonies have been reported on El Hierro (probably due to the impact of diseases and drought) where $18 \%$ of the analyzed colonies contained the $\mathrm{C}$ haplotype in a previous analysis (De la Rúa et al., 2001). Accordingly, local beekeepers are again interested in using selected Canary honey bees from La Palma in their colonies. Thus, we suggest genotyping individually mated queens from the natural mating area prior to their introduction into other islands - as an effective conservation measure.

\section{ACKNOWLEDGEMENTS}

We thank Carmela García Castaños and the beekeepers from La Palma for providing honey bee samples and beekeeping information. Financial support was provided by "Consejería de Agricultura, Ganadería, Pesca y Alimentación" of the Canary Islands Government, the "Fundación Séneca" (project 11961/PI/09) and the Spanish Ministry of Education (IM).

\section{REFERENCES}

Allendorf F. W., England P. R., Luikart G., Ritchie P. A., Ryman N. (2008) - Genetic effects of harvest on wild animal populations. Trends in Ecol. Evol., 23: 327-337.

Cánovas F., De la Rúa P., Serrano J., Galián J. (2008) - Geographical patterns of mitochondrial DNA variation in Apis mellifera iberiensis (Hymenoptera: Apidae). J. Zool. Sys. Evol. Res., 46: 24-30.

Clarke K. E., Rinderer T. E., Franck P., Quezada-Euán J. G., Oldroyd B. P. (2002) - The Africanization of honey bees (Apis mellifera L.) of the Yucatan: a study of a massive hybridization event acrosstime. Evolution, 56: 1462-1474.
De la Rúa P., Serrano J., Galián J. (1998) - Mitochondrial DNA variability in the Canary Island honey bees (Apis mellifera L.). Mol. Ecol., 7: 1543-1548.

De la Rúa P., Galián J., Serrano J., Moritz R. F. A. (2001) - Genetic structure and distinctness of Apis mellifera L. populations from the Canary Islands. Mol. Ecol., 10: 1733-1742.

De la Rúa P., Galián J., Serrano J. (2002) - Biodiversity of Apis mellifera populations from Tenerife (Canary Islands) and hybridization with East European races. Biodivers. Conserv., 11: 59-67.

De la Rúa P., Galián J., Pedersen B. V., Serrano J. (2006) - Molecular characterization and population structure of Apis mellifera from Madeira and the Azores. Apidologie, 37: 699-708.

De la Rúa P., Radloff S., Hepburn R., Serrano J. (2007) - Do molecular markers support morphometric and pheromone analyses? A preliminary case study in Apis mellifera populations of Morocco. Arch. Zootec., 56: 33-42.

De la Rúa P., Jaffé R., Dall'Olio R., Muñoz I., Serrano J. (2009)- Biodiversity, conservation and current threats to European honey bees. Apidologie, 40: 263-284.

El-Niweiri M. A. A., Moritz R. F. A. (2010) - The impact of apiculture on the structure of wild honey bee populations (Apis mellifera) in Sudan. J. Insect. Conserv., 14: 115-124.

Estoup A., Garnery L., Solignac M., Cornuet J. M. (1995) - Microsatellite variation in honey bee (Apis mellifera L.) populations: Hierarchical genetic structure and test of the infinite allele and stepwise mutation models. Genetics, 140: 679-695.

Excoffier L., Laval G., Schneider S. (2005) - Arlequin ver. 3.0: An integrated software package for population genetics data analysis. Evol. Bioinformatics Online, 1: 47-50.

Franck P., Garnery L., Loiseau A. (2001) - Genetic diversity of the honey bee in Africa: microsatellite and mitochondrial data. Heredity, 86: 420-430. 
Garnery L., Solignac M., Celebrano G., Cornuet J. M. (1993) - A simple test using restricted PCR-amplified mitochondrial DNA to study the genetic structure of Apis mellifera L. Experientia, 49: 1016-1021.

Goudet J. (2001) - FSTAT, a program to estimate and test gene diversities and fixation indices (version 2.9.3). Heredity, 86: 485-486.

Guo S., Thompson E. (1992) - Performing the exact test of Hardy-Weinberg proportion for multiple alleles. Biometrics, 48: 361-372.

Jensen A. B., Palmer K. A., Boomsma J. J., Pedersen B. V. (2005) - Varying degrees of Apis mellifera ligustica introgression in protected populations of the black honey bee, Apis mellifera mellifera, in northwest Europe. Mol. Ecol., 14: 93-106.

Martín J. L., Marrero M., Zurita N., Arechavaleta M., Izquierdo I. (2005) Biodiversidad en gráficas. Especies silvestres de las Islas Canarias. Consejería de Medio Ambiente y Ordenación Territorial, Gobierno de Canarias, Santa Cruz de Tenerife.

Miguel I., Iriondo M., Garnery L., Sheppard W. S., Estonba A. (2007) Gene flow within the M evolutionary branch of Apis mellifera: role of the Pyrenees, isolation by distance and post glacial re-colonization routes in the Western Europe. Apidologie, 38: 141-155.

Moritz R. F. A., Härtel S., Neumann P. (2005) - Global invasions of the western honey bee (Apis mellifera) and the consequences for biodiversity. Ecoscience, 12: 289-301.
Padilla-Álvarez F., Puerta-Puerta F., Flores-Serrano J. M., Bustos-Ruiz M., Hernández-Fernández R. (1997) Biometrical study of bees on the island of $\mathrm{La}$ Palma. (I. Proboscis, hindleg, cubital index $\mathrm{A} / \mathrm{B}$, tergites and sternites 3 and 4). Arch. Zootec., 46: 21-30.

Peakall R., Smouse P. E. (2006) GENALEX 6: genetic analysis in Excel. Population genetic software for teaching and research. Mol. Ecol. Notes, 6: 288-295.

Rhymer J. M., Simberloff D. (1996) Extinction by hybridization and introgression. Annu. Rev. Ecol. Syst., 27: 83-109.

Rousset F. (2008) - Genepop'007: a complete reimplementation of the Genepop software for Windows and Linux. Mol. Ecol. Res., 8: 103-106.

Ruttner F. (1988) - Biogeography and Taxonomy of Honey bees. Springer Verlag, Berlin.

Tamura K., Dudley J., Nei M., Kumar S. (2007) - MEGA4: Molecular Evolutionary Genetics Analysis (MEGA) software version 4.0. Mol. Biol. Evol., 24: 1596-1599.

Walsh P. S., Metzqer D. A., Higuchi R. (1991) - Chelex 100 as a medium for simple extraction of DNA for PCR-based typing from forensic material. Biotechniques, 10: 506-512. 


\title{
OKRESOWA ANALIZA RÓŻNORODNOŚCI GENETYCZNEJ POPULACJI PSZCZÓŁ Z IZOLOWANEGO TRUTOWISKA NA WYSPIE (LA PALMA, WYSPY KANARYJSKIE, HISZPANIA)
}

\author{
Mũ̃oz I., De la Rúa P. \\ S t r e s z c z e n i e
}

W 2001 roku przyjęto ustawę o ochronie populacji pszczół na wyspie La Palma (Wyspy Kanaryjskie), a wprowadzanie obcych pododmian zostało zakazane. W północnowschodniej części wyspy utworzono naturalne trutowisko dla miejscowych matek pszczelich. Aby ocenić różnorodność genetyczną rodzin pszczelich na tym terenie, przeprowadzono analizę zmienności mitochondrialnej (region międzygenowytRNA ${ }^{\text {leu }}$-cox2) oraz jądrowej (pięć loci mikrosatelitanych) w oparciu o porównanie wyników badań przeprowadzonych w roku 1998 oraz 2006 (tj. przed i po wprowadzeniu programu ochrony w 2001 roku). $\mathrm{W}$ analizowanym okresie stwierdzono dużą różnicę w zmienności mitochondrialnej na obszarze objętym badaniami, podczas gdy na poziomie jądrowym takich różnic nie zaobserwowano. Uzyskane wyniki mogą być przydatne w kontrolowaniu wybranych rodzin pszczelich objętych programem ochrony. Jest to szczególnie istotne w przypadku wprowadzania rodzin pszczelich na inne wyspy archipelagu.

Słowa kluczowe: Apis mellifera, hodowla zachowawcza, różnorodność genetyczna, La Palma, Hiszpania. 